\title{
Respiratory viral infections among children with community-acquired pneumonia and pleural effusion
}

\author{
CRISTIANA M. NASCIMENTO-CARVALHO ${ }^{1}$, JULIANA R. OLIVEIRA ${ }^{2}$, \\ MARIA-REGINA A. CARDOSO ${ }^{3}$, CÉSAR ARAÚJO-NETO $^{4}$, ALDINA BARRAL $^{5}$, \\ ANNIKA SAUKKORIIPI ${ }^{6}$, MIKA PALDANIUS $^{6,7}$, MAIJA LEINONEN $^{6}$, \\ MAIJA LAPPALAINEN ${ }^{8}$, MARIA SÖDERLUND-VENERMO ${ }^{9}$, \\ RAIJA VAINIONPÄ ${ }^{10} \&$ OLLI RUUSKANEN ${ }^{11}$
}

From the ${ }^{1}$ Paediatrics Department, Federal University of Bahia School of Medicine, Salvador, ${ }^{2}$ Professor Hosannah de Oliveira Paediatric Centre, Federal University of Bahia, Salvador, ${ }^{3}$ Epidemiology Department, Faculty of Public Health, São Paulo University, São Paulo, ${ }^{4}$ Image Diagnosis Department, Federal University of Bahia School of Medicine, Salvador, ${ }^{5}$ Pathology Department, Federal University of Bahia School of Medicine, Salvador, Brazil, ${ }^{6}$ Bacterial Laboratory, National Institute for Health and Welfare, Oulu, ${ }^{7}$ Clinical Microbiology Laboratory, Oulu University Hospital, Oulu, ${ }^{8}$ Virology Laboratory, University Central Hospital Laboratory Division, Helsinki, ${ }^{9}$ Haartman Institute, University of Helsinki, Helsinki, ${ }^{10}$ Virology Department, University of Turku, Turku, and ${ }^{11}$ Paediatrics Department, University of Turku, Turku, Finland

\begin{abstract}
Pleural effusion (PE), a complication of community-acquired pneumonia (CAP), is usually attributed to a bacterial infection. Nonetheless, viral infections have not been investigated routinely. We searched for bacterial and viral infections among 277 children hospitalized with CAP. Among these children $206(74 \%)$ had radiographic confirmation, of whom 25 (12\%) had PE. The aetiology was established in $18(72 \%)$ PE cases: bacterial $(n=5 ; 28 \%)$, viral $(n=9 ; 50 \%)$, and viral-bacterial $(n=4 ; 22 \%)$ infections were found. Infection by rhinovirus $(n=3)$, enterovirus, Streptococcus pneumoniae $(n=2$ each), Haemophilus influenzae, Moraxella catarrhalis, Mycoplasma pneumoniae, influenza A virus, and respiratory syncytial virus (RSV) ( $n=1$ each) were detected as probable sole infections. Parainfluenza virus $1 / 3+$ influenza A virus and RSV + influenza A virus ( $n=1$ each) were identified as mixed viral-viral infections. Probable viral non-bacterial infection was identified in a third of the cases with CAP and PE. It is advisable to investigate viral as well as bacterial infections among children with CAP and PE.
\end{abstract}

Keywords: Acute respiratory infection, lower respiratory tract infection, pleural fluid, respiratory viruses, viral infection

\section{Introduction}

Community-acquired pneumonia (CAP) is a leading cause of childhood morbidity worldwide [1]. In developing countries, CAP is the first cause of childhood mortality in those aged under 5 y [2]. Several bacteria and viruses have been recognized as causative agents [1], and pleural effusion (PE) is the most common complication of CAP [3].Viruses have been recognized as the most frequent causative agents of CAP and a third of children have viral-bacterial coinfections, as the use of molecular techniques has enhanced the identification of pathogens [4]. A sharp increase from 18 up to 43 episodes of CAP with PE per 100,000 children under 5 y old has been registered recently [5]. Different studies have reported an association between bacterial infection and PE among children with CAP $[6,7]$. Nonetheless, to our knowledge, viral infections have not been investigated comprehensively in this scenario. The aim of this study was to describe the bacterial and viral aetiology among children hospitalized with CAP and $\mathrm{PE}$ by an extensive search for 18 pathogens.

Correspondence: C. M. Nascimento-Carvalho, Paediatrics Department, Federal University of Bahia School of Medicine, Rua Prof. Aristides Novis, No. 105/1201B, Salvador, CEP 40210-630, Bahia, Brazil. Tel: + 5571 32357869. Fax: + 557133320725 . E-mail: nascimentocarvalho@hotmail.com 


\section{Patients and methods}

Three hundred and thirty-two previously healthy children aged $<5$ y consecutively admitted to the university hospital in Salvador, Brazil with CAP, were prospectively enrolled. Written informed consent was obtained. Inclusion criteria comprised fever or dyspnoea plus respiratory complaints and the presence of a pulmonary infiltrate or PE on chest X-ray on admission by paediatrician reading. Exclusion was due to refusal to give informed consent $(n=28)$, chronic pulmonary disease except asthma $(n=6)$, HIV-infected mother $(n=6)$, chickenpox $(n=3)$, and immunodeficiency $(n=2)$. No patient had cancer, measles, or tuberculosis. A senior paediatric radiologist, blinded to the clinical-aetiological data, read the chest X-ray and registered the evaluation on a standardized form.

Upon enrolment, blood samples were collected for culture, serological assays, and pneumococcal polymerase chain reaction (PCR); nasopharyngeal aspirates (NPA) were collected for virus detection. Two to four weeks later, blood was collected for serological assays and comparison of titres. The investigation of aetiology comprised the performance of several tests to search for the same aetiological agent; this was carried out for every case presented herein.

Blood and PE specimens were immediately inoculated into appropriate broth media for culture. Isolates were identified by standard methods [8]. A pleural tap was performed at the discretion of the assistant paediatrician. Bacterial antibody assays were carried out on acute and convalescent serum samples. Antibodies against Streptococcus pneumoniae, non-typable Haemophilus influenzae, and Moraxella catarrhalis were measured using an inhouse enzyme immunoassay (EIA). For S. pneumoniae infections, immunoglobin $\mathrm{G}$ (IgG) antibodies to pneumococcal pneumolysin and pneumococcal C-polysaccharide were measured, and $a \geq 2$-fold increase in antibody titres between paired sera was considered diagnostic. For $H$. influenzae and $M$. catarrhalis infections, immunoglobulin (Ig; polyvalent) antibodies against whole bacterial cell antigens (a mixture of 10 different strains) were measured and $a \geq 3$-fold antibody increase between paired sera was considered diagnostic [9]. An in-house microimmunofluorescence test was used to measure IgG, IgA, and $\operatorname{IgM}$ antibodies to Chlamydia pneumoniae and Simkania negevensis, using purified, formalized elementary bodies of Kajaani 6 strain in C. pneumoniae tests [10] and ATCC strain Z (ATCC, catalogue No. VR-1471) in S. negevensis tests [11]. The diagnosis of acute infection was based on a $\geq 4$-fold increase in IgG or IgA antibodies between paired sera or on the presence of $\operatorname{IgM}$ antibodies. The detection limits were $1: 8$ for $\operatorname{IgG}, 1: 8$ for IgA, and 1:10 for IgM antibodies. Chlamydia trachomatis IgG antibodies were measured using a commercial, solid-phase EIA (Ani Labsystems Ltd, Vantaa, Finland). Laboratory diagnosis was based on signal to cut-off (S/CO) values, which were $\geq 1.4 \mathrm{~S} / \mathrm{CO}$. Positive values $\geq 1.4 \mathrm{~S} / \mathrm{CO}$ may indicate either a past or an acute ongoing infection [12]. PCR was used for the detection of S. pneumoniae DNA in blood buffy-coat [13] after extraction of DNA using a QIAamp DNA Blood Mini Kit (Qiagen, Hilden, Germany). These tests were carried out at the National Institute for Health and Welfare, Oulu, Finland, and the samples were shipped from Salvador to Oulu at $-70^{\circ} \mathrm{C}$ by airplane. IgM antibodies to Mycoplasma pneumoniae were measured using a commercial EIA kit (Platelia, Bio-Rad, Marnes la Coquette, France) at the Centro de Pesquisa Gonçalo Muniz, Fundação Oswaldo Cruz, in Salvador, Brazil. The presence of IgM was indicative of an acute infection [14].

Viral antigens (influenza A and B viruses, respiratory syncytial virus (RSV), parainfluenza virus types 1 , 2, and 3, and adenovirus) in NPA were searched for using a time-resolved fluoroimmunoassay with monoclonal antibodies [15]. Virus-specific serum antibody titres were determined using an EIA with an antigencoated solid phase and horseradish peroxidase-conjugated rabbit antihuman IgG (Dako, Glostrup, Denmark) [15]; a 3-fold rise in IgG titres between paired samples was considered diagnostic. A PCR assay was used for the detection of rhinoviruses and enteroviruses [16]. These virological studies were carried out at the Department of Virology, Turku University Hospital, Turku, Finland, and the serum and NPA samples were shipped from Salvador to Turku at $-70^{\circ} \mathrm{C}$ by air. Human metapneumovirus (HMPV) RNA was detected by reverse transcription (RT) PCR in NPA. The HMPV investigation was carried out at the Virology Laboratory, University Central Hospital Laboratory Division, Helsinki, Finland. Human bocavirus $(\mathrm{HBoV})$ infection was searched for by measuring $\mathrm{HBoV}$ IgG, the m-capture IgM, and the IgG avidity EIA [17]. Recombinant viruslike particles ofVP2 were used as antigen in the 3 EIAs. HBoV multiplex qPCR of serum was performed to further study the children with a diagnostic IgG increase without IgM or low IgG avidity [18]. The diagnostic criteria for an acute primary $\mathrm{HBoV}$ infection were the presence of 2 or more of the following markers: presence of $\operatorname{IgM}$, a 4-fold or greater increase or conversion of IgG in paired sera, low avidity of IgG, or positive qPCR in serum. The $\mathrm{HBoV}$ investigation was carried out at the Haartman Institute, University of Helsinki, Helsinki, Finland. Samples were shipped from Turku to Helsinki at $-70^{\circ} \mathrm{C}$. 
The 2-tailed Fisher's exact test and Mann-Whitney $U$-test (significance level 0.05) were used for comparisons between categorical and continuous variables, respectively. The study was approved by the institutional ethics committee.

\section{Results}

Out of 277 enrolled children, 206 (74\%) had a radiographic diagnosis confirmed by the radiologist. PE was described in $25(12 \%)$ cases among whom the aetiology was established in 18 (72\%); 5 bacterial (28\%), 9 viral $(50 \%)$, and 4 viral-bacterial (22\%) infections were found. Among PE cases, there were 18 (72\%) males, and age ranged from 5 to 59 months (median and mean were 23 and $25 \pm 18$ months, respectively). Previous use of oral antibiotics was reported for 4 $(16 \%)$. Antibiotic use was higher among those without a detected aetiology ( $43 \%$ vs $6 \%$; $p=0.05)$.

Table I shows the cases with detected pathogens and the diagnostic criteria for PE and for aetiology. None of the patients with a bacterial infection reported previous antibiotic use in comparison to 1 patient with an exclusively viral infection $(0 \%$ vs $11 \% ; p=1)$. Among the 18 patients with a detected aetiology, 12 $(67 \%)$ were males. The same proportion was identified by considering the subgroups with exclusively viral or bacterial infections. A pleural tap was performed in $6(33 \%)$ cases: 4 had non-purulent fluid and 2 had purulent fluid. Among those with nonpurulent pleural fluid, infection by S. pneumoniae, M. pneumoniae, rhinovirus, and RSV was found, whereas among those with drainage of purulent pleural fluid, infection by enterovirus and influenza $A$ virus was detected. Five patients had a pneumococcal infection diagnosed: 3 by increased IgG serum titres, 1 by serum PCR, and 1 by blood culture.

Table II presents clinical-radiological data on admission and evolution. All patients reported fever, cough, and dyspnoea; chest indrawing and reduced pulmonary expansion were identified in $12(67 \%)$ and $10(56 \%)$ of them, respectively. The only child who died had congenital heart disease and a pulmonary infection attributable to RSV and influenza A virus. Disease length (days) was longer among children with exclusively viral infections than among those with bacterial infections (median $\left(25^{\text {th }}-75^{\text {th }}\right.$ percentile): 7 (6-17) vs $5(3.5-5.5), p=0.02)$. No significant difference was found in age (median $\left(25^{\text {th }}-75^{\text {th }}\right.$ percentile): $19(8-33)$ vs $24(12-50)$ months, $p=0.4)$ or length of hospital stay (median $\left(25^{\text {th }}-75^{\text {th }}\right.$ percentile): $11(7-17)$ vs $6(4.5-12)$ days, $p=0.2)$ when comparing the same subgroups. The frequency of each pathogen among all children with CAP irrespective of presenting PE has been published previously [19].

\section{Discussion}

Interestingly, probable viral non-bacterial infections were identified among a third of children hospitalized with CAP and PE. In a British study using molecular diagnostic techniques to search for bacterial infections among children with empyema, no aetiology was found in $25 \%$ of the cases [20]. In that study, viruses were not searched for. In an American study, the aetiological agents were identified in 34\% of 32 children with CAP and PE, in spite of searching for both viral and bacterial infections. Those authors used only viral culture to search for rhinoviruses and enteroviruses and this methodological difference may be the reason for the distinct results [7]. An association between bacterial infection and PE among children with CAP has been reported $[6,7]$. Investigation of only bacterial infections has been the rule in the aetiological studies of CAP with PE [5]. Therefore, methodological constraints might have yielded biased results. In the study by Hijazi et al. [6] in Kuwait, only respiratory syncytial virus, influenza $A$ and $B$ viruses, parainfluenza virus types 1 and 3 , and adenovirus were investigated. Actually, the majority of the viral infections reported in our study were attributable to rhinoviruses and enteroviruses detected by PCR assays. Enteroviruses have been detected by PCR in the pleural fluid of an immunocompromised patient after the development of pneumonia with PE [21]. In immunocompetent paediatric patients, the pathogenic effect of rhinovirus has been associated with lower respiratory tract infections in the absence of other viral agents when the viral load is high [22]. Notably, for exclusively viral infections the time taken before the parents sought health assistance for the children was longer. It is possible that viral infections had a milder presentation since bacterial infections have been associated with more severe disease [1].

An impact of pre-treatment with antibiotics on the detection of the causative agent was observed. Although the difference on statistical analysis was borderline, it was of interest from the clinical point of view. It is possible to suspect that more cases would have the aetiology detected if there was no previous use of antibiotics. In such cases, the expected pathogen would be bacterial. Nonetheless, the previous use of antibiotics did not seem to influence the distribution of aetiology among those with detected pathogens.

This study has limitations that must be emphasized: the investigation of each pathogen was performed by searching for its presence in the host or the host response to the pathogen's presence. Moreover, the clearance of the infective organism was not documented at the convalescent visit. Only 1 pneumococcal 
Table I. The demographic data and diagnostic criteria for pleural effusion and for the aetiology in each case of community-acquired pneumonia with pleural effusion with the probable causative agent detected.

\begin{tabular}{|c|c|c|c|c|}
\hline Case & $\begin{array}{l}\text { Age } \\
\text { (months)/ } \\
\text { gender }\end{array}$ & Pleural effusion diagnosis & Probable aetiology & Aetiological diagnostic criteria \\
\hline 317 & $15 /$ female & $\begin{array}{l}\text { Costophrenic angle opacity up to the top of } \\
\text { the hemithorax }\end{array}$ & $\begin{array}{l}\text { Streptococcus } \\
\text { pneumoniae }\end{array}$ & Serum positive PCR \\
\hline 39 & $33 /$ male & $\begin{array}{l}\text { Costophrenic angle opacity up to the top of } \\
\text { the hemithorax; thoracentesis: non- } \\
\text { purulent fluid }\end{array}$ & $\begin{array}{l}\text { Streptococcus } \\
\text { pneumoniae }\end{array}$ & $\begin{array}{l}\text { Serum IgG to C-polysaccharide } \\
\quad \text { (from } 8903 \text { to } 241,894 \text { ) }\end{array}$ \\
\hline 276 & $51 /$ male & Flowing fluid on lateral decubitus view & $\begin{array}{l}\text { Haemophilus } \\
\text { influenzae }\end{array}$ & $\begin{array}{l}\text { Serum IgG titre increase (from } \\
12,014 \text { to } 82,585 \text { ) }\end{array}$ \\
\hline 263 & $10 /$ male & $\begin{array}{l}\text { Costophrenic angle opacity up to the } \\
\text { middle of the hemithorax }\end{array}$ & $\begin{array}{l}\text { Moraxella } \\
\text { catarrhalis }\end{array}$ & $\begin{array}{l}\text { Serum IgG titre increase (from } \\
1144 \text { to } 6801 \text { ) }\end{array}$ \\
\hline 9 & $48 /$ male & $\begin{array}{l}\text { Costophrenic angle opacity up to the } \\
\text { middle of the hemithorax; thoracentesis: } \\
\text { non-purulent fluid }\end{array}$ & $\begin{array}{l}\text { Mycoplasma } \\
\text { pneumoniae }\end{array}$ & Serum IgM antibodies \\
\hline $40^{\mathrm{a}}$ & 6/female & Flowing fluid on lateral decubitus view & Rhinovirus & Positive PCR in NPA \\
\hline 43 & $38 /$ female & $\begin{array}{l}\text { Costophrenic angle opacity up to the } \\
\text { middle of the hemithorax; ultrasound: } \\
\text { free fluid up to the top }\end{array}$ & Rhinovirus & Positive PCR in NPA \\
\hline 204 & 59/male & $\begin{array}{l}\text { Costophrenic angle opacity up to the top of } \\
\text { the hemithorax pushing the mediastinum; } \\
\text { thoracentesis: non-purulent fluid }\end{array}$ & Rhinovirus & Positive PCR in NPA \\
\hline 116 & 5/female & $\begin{array}{l}\text { Costophrenic angle opacity up to the top of } \\
\text { the hemithorax pushing the mediastinum; } \\
\text { drainage of purulent fluid for } 4 \text { days }\end{array}$ & Enterovirus & Positive PCR in NPA \\
\hline 251 & $26 /$ male & $\begin{array}{l}\text { Costophrenic angle opacity up to the lower } \\
\text { third part of the hemithorax }\end{array}$ & Enterovirus & Positive PCR in NPA \\
\hline 303 & $10 /$ male & $\begin{array}{l}\text { Costophrenic angle opacity up to the top of } \\
\text { the hemithorax; thoracentesis: non- } \\
\text { purulent fluid }\end{array}$ & RSV & $\begin{array}{l}\text { NPA antigen detection }+ \text { serum } \\
\text { IgG (from }<40 \text { to } 1280 \text { ) }\end{array}$ \\
\hline 96 & $18 /$ male & $\begin{array}{l}\text { Costophrenic angle opacity up to the top of } \\
\text { the hemithorax; drainage of purulent } \\
\text { fluid for } 2 \text { days }\end{array}$ & Influenza $\mathrm{A}$ virus & $\begin{array}{l}\text { NPA antigen detection }+ \text { serum } \\
\text { IgG (from } 1 \text { to } 3 \text { ) }\end{array}$ \\
\hline 55 & $25 /$ male & $\begin{array}{l}\text { Costophrenic angle opacity up to the top of } \\
\text { the hemithorax }+1 \text { diaphragm on lateral } \\
\text { view }\end{array}$ & $\begin{array}{l}\text { Parainfluenza virus } \\
\text { 1/3; influenza A } \\
\text { virus }\end{array}$ & $\begin{array}{l}\text { Serum IgG titre increase (from } \\
32 \text { to } 191 \text { ); serum IgG titre } \\
\text { increase (from } 1 \text { to } 3 \text { ) }\end{array}$ \\
\hline $225^{\mathrm{b}}$ & $9 /$ male & $\begin{array}{l}\text { Costophrenic angle opacity up to the top of } \\
\text { the hemithorax pushing the mediastinum }\end{array}$ & $\begin{array}{l}\text { RSV; influenza A } \\
\text { virus }\end{array}$ & NPA antigen detection \\
\hline 220 & $23 /$ female & $\begin{array}{l}\text { Costophrenic angle opacity up to the } \\
\text { middle of the hemithorax }+1 \text { diaphragm } \\
\text { on lateral view }\end{array}$ & $\begin{array}{l}\text { Parainfluenza virus } \\
1 / 3 \text {; } \\
\text { Streptococcus } \\
\text { pneumoniae }\end{array}$ & $\begin{array}{l}\text { Serum IgG titre increase } \\
\text { (from }<1 \text { to } 30 \text { ); serum IgG } \\
\text { to C-polysaccharide (from } 22 \\
\text { to } 2849 \text { ) }\end{array}$ \\
\hline 297 & $9 /$ male & $\begin{array}{l}\text { Costophrenic angle opacity up to the lower } \\
\text { third part of the hemithorax }\end{array}$ & $\begin{array}{l}\text { Enterovirus; } \\
\text { Streptococcus } \\
\text { pneumoniae }\end{array}$ & $\begin{array}{l}\text { Positive PCR in NPA } \\
\text { Serum IgG to C-polysaccharide } \\
\quad \text { (from } 4558 \text { to } 10,572 \text { ) }\end{array}$ \\
\hline 137 & $52 /$ female & Thickening of the inter-lobar fissure & $\begin{array}{l}\text { RSV; influenza B } \\
\text { virus; Simkania } \\
\text { negevensis }\end{array}$ & $\begin{array}{l}\text { Serum IgG titre increase (from } \\
1280 \text { to } 10,240 \text { ); NPA } \\
\text { antigen detection }+ \text { serum } \\
\text { IgG (from } 24 \text { to } 239 \text { ); serum } \\
\text { IgM antibodies }\end{array}$ \\
\hline 261 & $15 /$ male & $\begin{array}{l}\text { Elevation of the diaphragm and lens like } \\
\text { image: loculated pleural fluid }\end{array}$ & $\begin{array}{l}\text { Parainfluenza virus } \\
\text { 3; HBoV; } \\
\text { Streptococcus } \\
\text { pneumoniae }\end{array}$ & $\begin{array}{l}\text { NPA antigen detection }+ \text { serum } \\
\text { IgG (from } 4 \text { to } 16 \text { ); serum } \\
\text { IgM antibodies }+ \text { low IgG } \\
\text { avidity; blood culture } \\
\text { isolation }^{c}\end{array}$ \\
\hline
\end{tabular}

HBoV, human bocavirus; NPA, nasopharyngeal aspirates; PCR, polymerase chain reaction; RSV, respiratory syncytial virus; Infection by Chlamydia trachomatis, Chlamydia pneumoniae, parainfluenza virus type 2, adenovirus, or human metapneumovirus was not identified. All cases presented a vaccination card, received Haemophilus influenzae type $b$ vaccine, and did not receive pneumococcal vaccine.

a Pre-hospital cefalexin use.

${ }^{b}$ Lost to follow-up visit because the patient died on day 5 of hospitalization.

'Pneumococcal serotype was 14 according to the Public Meningitis, Pneumonia and Pneumococcal Infections Core (National Reference Laboratory), Bacteriology Centre of the Adolfo Lutz Institute, São Paulo, Brazil. 
Table II. Clinical-radiological data on admission and evolution of children hospitalized with community-acquired pneumonia and pleural effusion with probable aetiology detected.

\begin{tabular}{|c|c|c|c|c|}
\hline Case & $\begin{array}{c}\text { Disease } \\
\text { length (days) }\end{array}$ & $\begin{array}{l}\text { Radiological inclusion } \\
\text { criteria }\end{array}$ & $\begin{array}{l}\text { Respiratory physical findings on } \\
\text { admission }\end{array}$ & $\begin{array}{l}\text { Length of stay } \\
\text { (days)/outcome }\end{array}$ \\
\hline 9 & 8 & $\begin{array}{c}\text { Alveolar infiltrate left } \\
\text { lower lobe and PE }\end{array}$ & $\begin{array}{l}\text { Chest indrawing and retraction, } \\
\text { crackles, tubal murmur }\end{array}$ & 13/discharged \\
\hline $39^{\mathrm{a}}$ & 6 & PE & $\begin{array}{l}\text { Chest indrawing and retraction, } \\
\text { crackles }\end{array}$ & 20/discharged \\
\hline 40 & 7 & $\mathrm{PE}$ & $\begin{array}{l}\text { Chest indrawing and retraction, } \\
\text { crackles, tubal murmur }\end{array}$ & 7/discharged \\
\hline $43^{\mathrm{a}}$ & 14 & PE & Crackles & $11 /$ discharged \\
\hline $55^{\mathrm{a}}$ & 5 & $\begin{array}{c}\text { Alveolar infiltrate left } \\
\text { lower lobe and PE }\end{array}$ & Chest indrawing, crackles & 10/discharged \\
\hline $96^{\mathrm{a}}$ & 19 & PE & $\begin{array}{l}\text { Chest indrawing and retraction, } \\
\text { tubal murmur }\end{array}$ & 15/discharged \\
\hline $116^{\mathrm{a}}$ & 7 & PE & Clavicular retraction & 19/discharged \\
\hline 137 & 3 & $\begin{array}{l}\text { Alveolar infiltrate right } \\
\text { lower lobe and PE }\end{array}$ & $\begin{array}{l}\text { Chest indrawing and retraction, } \\
\text { crackles }\end{array}$ & Transferred \\
\hline $204^{\mathrm{a}}$ & 7 & $\begin{array}{l}\text { Alveolar infiltrate right } \\
\text { lower lobe and PE }\end{array}$ & Crackles & 12/discharged \\
\hline $220^{\mathrm{a}}$ & 5 & $\begin{array}{l}\text { Alveolar infiltrate left } \\
\text { lower lobe and PE }\end{array}$ & $\begin{array}{l}\text { Chest indrawing and retraction, } \\
\text { crackles, wheezing, tubal } \\
\text { murmur }\end{array}$ & 4/discharged \\
\hline 225 & 30 & PE & $\begin{array}{l}\text { Chest indrawing and retraction, } \\
\text { crackles }\end{array}$ & $5 /$ death $^{b}$ \\
\hline 251 & 3 & $\begin{array}{l}\text { Alveolar infiltrate right } \\
\text { lower lobe and PE }\end{array}$ & $\begin{array}{l}\text { Chest indrawing and retraction, } \\
\text { crackles }\end{array}$ & 4/discharged \\
\hline $261^{\mathrm{a}}$ & 4 & PE & Tubal murmur & 6/discharged \\
\hline 263 & 5 & $\begin{array}{l}\text { Alveolar infiltrate right } \\
\text { lower lobe and } \mathrm{PE}\end{array}$ & Chest retraction, crackles & 4/discharged \\
\hline $276^{\mathrm{a}}$ & 4 & $\begin{array}{l}\text { Alveolar infiltrate right } \\
\text { lower lobe and } \mathrm{PE}\end{array}$ & Chest indrawing and retraction & 6/discharged \\
\hline 297 & 3 & $\begin{array}{l}\text { Alveolar infiltrate right } \\
\text { upper lobe and PE }\end{array}$ & Chest indrawing, wheezing & 8/discharged \\
\hline 303 & 8 & $\begin{array}{l}\text { Alveolar infiltrate right } \\
\text { upper lobe and } \mathrm{PE}\end{array}$ & Crackles & 20/discharged \\
\hline $317^{\mathrm{a}}$ & 5 & $\begin{array}{l}\text { Alveolar infiltrate left } \\
\text { upper and lower } \\
\text { lobes and PE }\end{array}$ & $\begin{array}{l}\text { Chest indrawing and retraction, } \\
\text { crackles, wheezing }\end{array}$ & 4/discharged \\
\hline
\end{tabular}

PE, pleural effusion. All cases were included with fever, cough, and dyspnoea as presenting complaints.

${ }^{\text {a }}$ Reduced pulmonary expansion.

${ }^{\mathrm{b}}$ The patient had congenital heart disease.

infection case had the serotype determined. This analysis was based on only a small number of cases $(n=25)$, which increases the potential for chance findings. Also classic bacterial agents of PE like Staphylococcus aureus and group A streptococcal infections were searched for only by performing blood or pleural effusion culture. Six of our 9 exclusively viral infections were diagnosed only by virus detection in the NPA (Table I). Detection of a virus in the nasopharynx does not necessarily mean that the patient has pneumonia induced by that virus, as its presence may be due to persistence, prolonged shedding, mucosal contamination, or just an upper respiratory tract infection. However, HBoV NPA PCR-positive children with non-diagnostic serology were not classified as having an $\mathrm{HBoV}$ infection since it has been shown that serology is the reliable method to diagnose acute infection [23]. Ideally, the aetiology of PE should be established by showing the presence of the causative agent in the PE. Therefore, our results raise the necessity to investigate PE aetiology by searching for bacterial and viral agents in the pleural fluid using molecular methods to detect all possible causative agents, i.e., the aetiological investigation should not be restricted to bacterial infections. In this study it is likely that a viral non-bacterial infection was identified in a third of the cases with CAP and PE.

Declaration of interest: No conflict of interest.

This study was supported by the Fundação de Amparo à Pesquisa no Estado da Bahia (FAPESB), Salvador, Brazil, the Paediatric Research Foundation, the Helsinki University Central Hospital Research 
and Development Fund, the Academy of Finland (project 1122539), the Helsinki University Funds, the Medical Society of Finland, and the Sigrid Jusélius Foundation, Helsinki, Finland. C. M. NascimentoCarvalho, M.-R. A. Cardoso, and A. Barral are investigators of the Brazilian Council for Science and Technology Development (CNPq).

\section{References}

[1] Rudan I, Boschi-Pinto C, Biloglav Z, Mulholland K, Campbell H. Epidemiology and etiology of childhood pneumonia. Bull World Health Organ 2008;86:408-16.

[2] Liu L, Johnson HL, Cousens S, Perin J, Scott S, Lawn JE, et al. Global, regional, and national causes of child mortality: an update systematic analysis for 2010 with time trends since 2000. Lancet 2012;12:2151-61.

[3] Chetty K, Thomson AH. Management of community-acquired pneumonia in children. Paediatr Drugs 2007;9:401-11.

[4] Ruuskanen O, Lahti E, Jennings LC, Murdoch DR. Viral pneumonia. Lancet 2011;377:1264-75.

[5] Deiros Bronte L, Baquero-Artigao F, García-Miguel MJ, Hernández González N, Pena García P, del Castillo Martín F. Parapneumonic pleural effusion: an 11-year review. An Pediatr (Barc) 2006;64:40-5.

[6] Hijazi Z, Pacsa A, el-Gharbawy F, Chugh TD, Essa S, el Shazli A, et al. Acute lower respiratory tract infections in children in Kuwait. Ann Trop Paediatr 1997;17:127-34.

[7] Michelow IC, Olsen K, Lozano J, Rollins NK, Duffy LB, Ziegler T, et al. Epidemiology and clinical characteristics of community-acquired pneumonia in hospitalized children. Pediatrics 2004;113:701-7.

[8] Murray PR, Baron EJ, Jorgensen JH, Landry ML, Pfaller MA. Manual of clinical microbiology. $9^{\text {th }}$ ed. American Society for Microbiology; 2007.

[9] Nohynek H, Eskola J, Kleemola M, Jalonen E, Saikku P, Leinonen $\mathrm{M}$. Bacterial antibody assays in the diagnosis of acute lower respiratory tract infection in children. Pediatr Infect Dis J 1995;14:478-84.

[10] Wang S. The microimmunofluorescence test for Chlamydia pneumoniae infection: technique and interpretation. J Infect Dis 2000;181:S421-5.

[11] Korppi M, Paldanius M, Hyvarinen A, Nevalainen A. Simkania negevensis and newly diagnosed asthma: a case-control study in 1- to 6-year-old children. Respirology 2006;11:80-3.
[12] Morré SA, Munk C, Persson K, Kruger-Kjaer S, van Dijk R, Meijer CJ, et al. Comparison of three commercially available peptide-based immunoglobulin $\mathrm{G}$ ( $\operatorname{IgG}$ ) and $\operatorname{IgA}$ assays to microimmunofluorescence assay for detection of Chlamydia trachomatis antibodies. J Clin Microbiol 2002;40:584-7.

[13] Saukkoriipi A, Palmu A, Kilpi T, Leinonen M. Real-time quantitative PCR for the detection of Streptococcus pneumoniae in the middle ear fluid of children with acute otitis media. Mol Cell Probes 2002;16:385-90.

[14] Waris M, Toikka P, Saarinen T, Nikkari S, Meurman O, Vainionpaa R, et al. Diagnosis of Mycoplasma pneumoniae pneumonia in children. J Clin Microbiol 1998;36:3155-9.

[15] Mäkelä MJ, Puhakka T, Ruuskanen O, Leinonen M, Saikku P, Kimpimaki $M$, et al. Viruses and bacteria in the etiology of the common cold. J Clin Microbiol 1998;36:539-42.

[16] Hyypiä T, Puhakka T, Ruuskanen O, Mäkelä M, Arola A, Arstila P. Molecular diagnosis of human rhinovirus infection: comparison with virus isolation. J Clin Microbiol 1998;36:2081-3.

[17] Soderlund-Venermo M, Lahtinen A, Jartti T, Hedman L, Kemppainen K, Lehtinen P, et al. Clinical assessment and improved diagnosis of bocavirus-induced wheezing in children, Finland. Emerg Infect Dis 2009;15:1423-30.

[18] Kantola K, Sadeghi M, Antikainen J, Kirveskari J, Delwart E, Hedman K, et al. Real-time quantitative PCR detection of four human bocaviruses. J Clin Microbiol 2010;48:4044-50.

[19] Nascimento-Carvalho CM, Ribeiro CT, Cardoso MR, Barral A, Araújo-Neto CA, Oliveira JR, et al. The role of respiratory viral infections among children hospitalized for communityacquired pneumonia in a developing country. Pediatr Infect Dis J 2008;27:939-41.

[20] Saglani S, Harris KA, Wallis C, Hartley JC. Empyema: the use of broad range $16 \mathrm{~S}$ rDNA PCR for pathogen detection. Arch Dis Child 2005;90:70-3.

[21] Galama JM, de Leeuw N, Wittebol S, Peters H, Melchers WJ. Prolonged enteroviral infection in a patient who developed pericarditis and heart failure after bone marrow transplantation. Clin Infect Dis 1996;22:1004-8.

[22] Gerna G, Piralla A, Rovida F, Rognoni V, Marchi A, Locatelli F, et al. Correlation of rhinovirus load in the respiratory tract and clinical symptoms in hospitalized immunocompetent and immunocompromised patients. J Med Virol 2009;81:1498-507.

[23] Nascimento-Carvalho CM, Cardoso MR, Meriluoto M, Kemppainen K, Kantola K, Ruuskanen O, et al. Human bocavirus infection diagnosed serologically among children admitted to hospital with community-acquired pneumonia in a tropical region. J Med Virol 2012;84:253-8. 